\title{
EFFECT OF NITROGEN ON ACHENE PROTEIN, OIL, FATTY ACID PROFILE, AND YIELD OF SUNFLOWER HYBRIDS
}

\author{
Amjed Ali ${ }^{*}$, and Sami Ullah ${ }^{2}$
}

Seed yield and achene oil yield are the main determinants for $\mathrm{N}$ application rates rather than seed composition. Nitrogen plays a critical role in producing unsaturated fatty acids (oleic and linoleic acids), which are the main factors determining sunflower oil quality (Helianthus annuus L.). Studies were conducted on the effect of $\mathrm{N}$ fertilization on seed yield, achene oil yield, and quality parameters of sunflower hybrids for two successive years (2010 and 2011) in a split plot arrangement under a randomized complete block design. The hybrids (Hysun-33 \& S-278) and N levels $\left(0,75,150\right.$, and $\left.225 \mathrm{~kg} \mathrm{ha}^{-1}\right)$ were allotted in main and sub-plots, respectively. Increasing $\mathrm{N}$ levels resulted in steady increases in yield, protein contents and linoleic acid, whereas oil contents and percentage of oleic acid responded negatively during both years. At the same time, crop oil yield was positively related to increased $\mathrm{N}$ supply with higher achene yield (AY). Palmitic acid varied from 5.27 to $6.42 \%$ and stearic acid ranged from 2.27 to $2.95 \%$. Hybrid S-278 exhibited significantly $(\mathrm{P}<0.05)$ higher AY $(3380 \mathrm{~kg}$ $\mathrm{ha}^{-1}$ ), oil content $(42.11 \%)$ than Hysun-33 (2968 $\mathrm{kg} \mathrm{ha}^{-1}$ and $40.75 \%$, respectively), while the opposite was true for protein content. Oil yield varied in response to $\mathrm{N}$ fertilizer, with a range of 34 to $37 \%$ providing the best quality traits in both seasons.

Key words: Fertilization, linoleic acid, oleic acid, palmitic acid, Helianthus annuus.

$\mathrm{G}$ lobal demand for vegetable oils/fats, both for food and other industrial purposes, is anticipated to expand vigorously. Pakistan is facing a severe shortage of edible oil because its domestic production is far below the consumption level. Consequently a major share of foreign exchange is expended on oil imports, which is increasing every year. Sunflower oil is gaining popularity in European and East Asian countries for salad and cooking oil and margarine production, which are based on oil composition and the absence of cholesterol. In oil seed crops, quality criteria are fatty acid composition of the seed oil and the intended use of the oil. Polyunsaturated cooking oils have been the driving force for the sunflower industry. The oleic acid (a monounsaturated fatty acid) content of oil seeds has important implications for product performance and consumer health. High oleic varieties have provided the opportunity for repositioning sunflower products at the premium end of the growing monounsaturated market. Ryland (2003) compared different vegetable oils and found that sunflower oil to be the healthiest due to its high oleic acid content. Sunflower a non-conventional oil seed crop that can improve edible oil production due to its high oil contents and wide adaptability to soils and climatic conditions. Bakht et al. (2006) concluded that one of the reasons for low sunflower seed production is

\footnotetext{
${ }^{1}$ Washington State University, Prosser, Washington 99350, USA. *Corresponding author (ali.amjed@wsu.edu).

${ }^{2}$ University of Sargodha, University College of Agriculture, Sargodha, 40100, Pakistan.

Received: 16 March 2012.
}

Accepted: 17 September 2012. the sowing of exotic hybrids that are not well suited to our environmental conditions. Zahoor et al. (2010) reported that sowing newly developed hybrids and optimum $\mathrm{N}$ rates are important management practices to increase edible oil production and reduce import bills.

Pakistanis farmers believe that more fertilizer and high grain yields are synonymous. A better understanding of the relationship between crop yield and $\mathrm{N}$ rate could help agronomists match fertilizer rates with plant requirements (Gao et al., 2012). Abbadi and Gerendas (2009) noted that optimal supply of $\mathrm{N}$ fertilizer in sunflower result in grain yield more efficiently than low supply of $\mathrm{N}$. Regina (2008) concluded that $\mathrm{N}$ is the most important element to increase grain protein content. Increasing $\mathrm{N}$ rates reduced seed oil percentages but increased seed yields and consequently increased oil yield per unit area (Zheljazkov et al., 2008; 2009). Therefore, the aim of this study was to evaluate the effect of different levels of $\mathrm{N}$ application on yield and quality traits of sunflower in order to achieve the optimum use of resources.

\section{MATERIALS AND METHODS}

The experiment was carried out at the Research Area of University College of Agriculture Sargodha (32 $05^{\prime} \mathrm{N}$, $72^{\circ} 67^{\prime}$ E) Pakistan, under irrigated semi-arid conditions during the spring seasons of 2010 and 2011. Table 1 presents weather data for sunflower growing season (March-June in 2010 and 2011), and Table 2 presents physical and chemical analysis of experimental soil. The experiment was laid out in a Split plot arrangement under randomized complete block design with three replicates, 
keeping net plot size $4.20 \times 8 \mathrm{~m}$. Sunflower hybrids (Hysun-33, S-278) were kept in main plots and $\mathrm{N}$ levels in sub plots. Nitrogen treatments were $0,75,150$, and 225 $\mathrm{kg} \mathrm{ha}{ }^{-1}$, i.e. $\mathrm{N}_{0}, \mathrm{~N}_{1}, \mathrm{~N}_{2}$, and $\mathrm{N}_{3}$, respectively.

The crop was sown by the dibbler method on $70-\mathrm{cm}-$ spaced ridges and at $22.5 \mathrm{~cm}$ plant spacing using a recommended seed rate of $7 \mathrm{~kg} \mathrm{ha}^{-1}$. Phosphorus and $\mathrm{K}$ was applied at the rate of $100-50 \mathrm{~kg} \mathrm{ha}^{-1}$, respectively. Nitrogen, $\mathrm{P}$, and $\mathrm{K}$ were applied in the form of urea, single super phosphate and sulfate of potash, respectively. Full doses of $\mathrm{P}$ and $\mathrm{K}$ and $1 / 3$ of $\mathrm{N}$ were applied at sowing and the remaining $2 / 3$ of $N$ was applied in two equal splits, at the first irrigation and $\mathrm{R}_{3}$ stage (immature bud elongates). All other cultural practices, such as weeding, water application and plant protection measures were standard for the crop.

The harvested crop was sun dried, and threshed and achene yield was recorded at $15 \%$ moisture contents, then total achene yield was multiplied with oil contents to calculate achene oil yield. Protein and oil contents of

Table1. Mean monthly weather data for sunflower growing season MarchJune in 2010 and 2011.

\begin{tabular}{|c|c|c|c|c|c|c|}
\hline \multirow[b]{2}{*}{ Months } & \multicolumn{2}{|c|}{$\begin{array}{c}\text { Mean } \\
\text { temperature }\end{array}$} & \multicolumn{2}{|c|}{$\begin{array}{l}\text { Total } \\
\text { rainfall }\end{array}$} & \multicolumn{2}{|c|}{$\begin{array}{l}\text { Mean relative } \\
\text { humidity }\end{array}$} \\
\hline & 2010 & 2011 & 2010 & 2011 & 2010 & 2011 \\
\hline & $-{ }^{\circ} \mathrm{C}$ & - & - & $n-$ & $-\%$ & - \\
\hline March & 22.5 & 21.3 & 9.2 & 7.11 & 58.5 & 59.4 \\
\hline April & 30.2 & 25.6 & 4.06 & 35.06 & 44.2 & 46.3 \\
\hline May & 32.7 & 33.8 & 2.04 & 8.89 & 44.9 & 38.5 \\
\hline June & 33.5 & 33.7 & 14.74 & 126.25 & 44.6 & 51.0 \\
\hline
\end{tabular}

Table 2. Physical and chemical analysis of experimental soil.

\begin{tabular}{lc}
\hline Soil parameter & Value \\
\hline Physical analysis & \\
Sand, \% & 23 \\
Silt, \% & 60 \\
Clay, \% & 17 \\
Textural class & Silty loam \\
Chemical analysis & \\
pH & 7.6 \\
Total soluble salts, \% & 15.02 \\
Organic matter, \% & 0.96 \\
Total N, \% & 0.06 \\
Available P, mg kg-1 & 16.8 \\
Available K, mg kg & \\
\end{tabular}

seed samples were determined with the nuclear magnetic resonance (NMR) technique (Wamsely, 1998). Sunflower seed oil obtained from each sample was analyzed to determine the relative composition of different fatty acids (oleic, linoleic, palmitic, and stearic acids) with a GC-9A fatty acid analyzer (Model MQA-7005, Oxford Institute, USA). Data collected were statistically analyzed for ANOVA using the Fisher's ANOVA technique. The least significant difference (LSD) test at 0.05 was used to compare means (Steel et al., 1997).

\section{RESULTS AND DISCUSSION}

\section{Achene protein contents (\%)}

There was a significant increase in protein contents with the increased $\mathrm{N}$ rates (Table 3). In 2010, the highest protein content $(19.80 \%)$ was recorded in treatment $\mathrm{N}_{3}$ (225 kg N ha ${ }^{-1}$ ) and lowest (15.33\%) in $\mathrm{N}_{0}$ (control). There were similar results in 2011 , which are in line with those of Nanjundappa et al. (2001) and Munir et al. (2007), who observed increased achene protein due to $\mathrm{N}$ application. Sunflower hybrids had a significant effect on protein content in achene. 'Hysun-33' attained significantly higher protein content $(18.23 \%)$ than 'S278 ' $(17.10 \%)$, which might be due to varying genetic potential of the hybrids. These results are in accordance with the findings of Roche et al. (2010) and Bukhsh et al. (2011) that different sunflower hybrids exhibit the differential response to protein content in achene due to their difference of genetic makeup.

\section{Achene oil contents (\%)}

Oil content in achene decreased with higher $\mathrm{N}$ levels (Table 3). Maximum oil content (42.40\%) was observed in treatment $\mathrm{N}_{0}$ and minimum oil content $(39.63 \%)$ in treatment $\mathrm{N}_{3}$ in 2010. Results were similar in 2011. These results are consistent with those of Abdel-Sabour and Abo El-Seoud (1996), Nanjundappa et al. (2001), Munir et al. (2007), and Nasim et al. (2012), who observed decreases in achene oil percentages with increased $\mathrm{N}$ application.

Table 3. Effect of nitrogen on achene protein, oil, and oleic and linoleic acid contents of two sunflower hybrids.

\begin{tabular}{|c|c|c|c|c|c|c|c|c|}
\hline \multirow[b]{2}{*}{ Treatments } & \multicolumn{2}{|c|}{ Achene protein } & \multicolumn{2}{|c|}{ Oil content } & \multicolumn{2}{|c|}{ Oleic acid in oil } & \multicolumn{2}{|c|}{ Linoleic acid in oil } \\
\hline & 2010 & 2011 & 2010 & 2011 & 2010 & 2011 & 2010 & 2011 \\
\hline & & & & - & & & 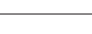 & $\overline{-}$ \\
\hline \multicolumn{9}{|l|}{ Hybrids } \\
\hline Hysun-33 & $18.02 \mathrm{a}$ & $18.23 \mathrm{a}$ & $39.97 b$ & $40.75 b$ & 40.21 & 40.09 & 46.30 & 46.76 \\
\hline S-278 & $17.10 \mathrm{~b}$ & $17.37 \mathrm{~b}$ & $41.95 \mathrm{a}$ & $42.11 \mathrm{a}$ & 40.30 & 40.25 & 46.27 & 46.60 \\
\hline LSD value & 0.33 & 0.33 & 0.42 & 0.40 & NS & NS & NS & NS \\
\hline \multicolumn{9}{|l|}{$\mathrm{N}$ levels } \\
\hline $\mathrm{N}_{0}$ (control) & $15.33 \mathrm{~d}$ & $15.60 \mathrm{~d}$ & $42.40 \mathrm{a}$ & $42.87 \mathrm{a}$ & $42.60 \mathrm{a}$ & $42.24 \mathrm{a}$ & $43.29 \mathrm{c}$ & $43.77 \mathrm{c}$ \\
\hline $\mathrm{N}_{1}\left(75 \mathrm{~kg} \mathrm{ha}^{-1}\right)$ & $16.92 \mathrm{c}$ & $16.98 \mathrm{c}$ & $41.48 b$ & $41.94 b$ & $41.17 \mathrm{~b}$ & $41.00 \mathrm{~b}$ & $45.37 \mathrm{~b}$ & $44.98 b$ \\
\hline $\mathrm{N}_{2}\left(150 \mathrm{~kg} \mathrm{ha}^{-1}\right)$ & $18.22 b$ & $18.53 b$ & $40.47 \mathrm{c}$ & $40.89 \mathrm{c}$ & $39.98 b$ & $39.85 b$ & $48.65 \mathrm{ab}$ & $48.83 \mathrm{ab}$ \\
\hline $\mathrm{N}_{3}\left(225 \mathrm{~kg} \mathrm{ha}^{-1}\right)$ & $19.80 \mathrm{a}$ & $20.09 \mathrm{a}$ & $39.63 d$ & $40.02 \mathrm{~d}$ & $38.25 \mathrm{c}$ & $38.30 \mathrm{c}$ & $49.00 \mathrm{a}$ & $49.15 a$ \\
\hline LSD value & 0.86 & 0.79 & 0.80 & 0.77 & 0.64 & 0.64 & 0.42 & 0.41 \\
\hline \multicolumn{9}{|l|}{ Interactions } \\
\hline Hybrids $\times \mathrm{N}$ & NS & NS & NS & NS & NS & NS & NS & NS \\
\hline
\end{tabular}

Any two means not sharing a letter are significantly different at 5\% level of probability (least significant difference LSD); NS: non significant. 
Sunflower hybrids have had a significant effect on oil content in achene. The S-278 hybrid showed significantly higher oil content $(41.95 \%, 42.11 \%)$ than 'Hysun-33' $(37.97 \%, 40.75 \%)$ in 2010 and 2011 , respectively, which might be due to the varying genetic potential of the hybrids The effect of the year was also not significant. These results are consistent with the findings of Roche et al. (2010) and Bukhsh et al. (2011), who found that different sunflower hybrids exhibit distinct responses to oil content in achene due to differences in their genetic makeup.

\section{Fatty acid composition (\%)}

Oleic and palmitic acid concentrations responded negatively to $\mathrm{N}$ application (Tables 3 and 4). In 2010, $\mathrm{N}_{0}$, had the highest oleic $(42.60 \%)$ and palmitic acid contents $(6.35 \%)$, followed by $\mathrm{N}_{1}$ and $\mathrm{N}_{2}$ having oleic acid concentrations of $41.17 \%$ and $39.18 \%$ and palmitic acid $5.95 \%$ and $5.90 \%$, respectively. Likewise, $\mathrm{N}_{3}$ had the lowest oleic $(38.25 \%)$ and palmitic acid concentrations $(5.27 \%)$. These results are supported by Nanjundappa et al. (2001), Munir et al. (2007), and Boydak et al. (2010), who observed decreases in the composition of this fatty acid with increased $\mathrm{N}$ application.

There was significant variation among different $\mathrm{N}$ treatments regarding linoleic acid concentration. $\mathrm{N}_{3}$ had the highest linoleic acid content $(49.00 \%)$, which was statistically similar to the $48.85 \%$ linoleic acid concentration obtained in $\mathrm{N}_{2}$, while the plots without $\mathrm{N}$ application had the lowest linoleic acid (43.29\%) contents. The highest stearic acid content (2.93\%) was obtained from $\mathrm{N}_{1}$, followed by $\mathrm{N}_{3}$, and the lowest was $1.90 \%$ from $\mathrm{N}_{2}$ with $1.9 \%$. These figures are from 2010 , but the tendencies were found in the next year of the experiment. Boydak et al. (2010) also observed these results in their experiments. Sunflower hybrids did not respond differentially to varying $\mathrm{N}$ levels in either year in terms of fatty acid composition.

\section{Achene and oil yield}

The response of achene yield (AY) and achene oil yield to increased applications of $\mathrm{N}$ fertilizer was significant
(Table 4). In 2010, a maximum AY of $3498 \mathrm{~kg} \mathrm{ha}^{-1}$ was observed in treatment $\mathrm{N}_{3}$, which was statistically at par with the AY (3485 $\mathrm{kg} \mathrm{ha}^{-1}$ ) of treatment $\mathrm{N}_{2}$ and followed by treatment $\mathrm{N}_{1}$ with an AY of $3192 \mathrm{~kg} \mathrm{ha}^{-1}$, while the lowest AY (2485 kg ha-1) was in the control plot where $\mathrm{N}$ was not applied. Results were similar in 2011. Sunflower hybrids had a significant effect on AY, 'S-278' had a higher achene $\left(3350,3380 \mathrm{~kg} \mathrm{ha}^{-1}\right)$ than 'Hysun-33' $\left(2980,2968 \mathrm{~kg} \mathrm{ha}^{-1}\right)$ in 2010 and 2011, respectively. These results are in line with the findings of Khaliq and Cheema (2005), Al-Thabet (2006), Nasim et al. (2011; 2012) who noted increased AY with different sunflower hybrids with increased $\mathrm{N}$ levels. The maximum oil yield $(1418,1433 \mathrm{~kg}$ ha $^{-1}$ ) was with $\mathrm{N}_{2}$, followed by $\mathrm{N}_{3}$ with AY $(1395,1409 \mathrm{~kg}$ $\mathrm{ha}^{-1}$ ) in 2010 and 2011, respectively. The lowest achene oil yield was with $\mathrm{N}_{0}$, in which increased $\mathrm{N}$ levels increased AY to a certain point, but after that achene oil yield was reduced due to a decrease in achene oil contents. These results are supported by Abdel-Sabour and Abo El-Seoud (1996) and Gholinezhad et al. (2011). Sunflower hybrids have significant effect on AY. Hybrid S-278 had higher achene oil yield (1405 and $1423 \mathrm{~kg} \mathrm{ha}^{-1}$ ) than Hysun-33 (1191 and $1209 \mathrm{~kg} \mathrm{ha}^{-1}$ ) in 2010 and 2011, respectively, which might be due to genetic characteristics of sunflower hybrids as explained by Flagella et al. (2002), Vega and Hall (2002), Thavaprakash et al. (2002), Zheljazkov et al. (2008), (2009), and Arshad et al. (2009), who also reported similar results regarding achene oil yield.

\section{CONCLUSION}

Sunflower hybrids exhibited differential genotypic responses to different $\mathrm{N}$ levels by increasing seed yields combined with achene oil yields. The hybrid S-278 had the highest achene yield (3350 and $3380 \mathrm{~kg} \mathrm{ha}^{-1}$ ) with more seed oil yield (1405 and $1423 \mathrm{~kg} \mathrm{ha}^{-1}$ ) and a better proportion of saturated and unsaturated fatty acids in both years. Higher achene yield (3485 and $3505 \mathrm{~kg} \mathrm{ha}^{-1}$ ) and oil yield (1418 and $1433 \mathrm{~kg} \mathrm{ha}^{-1}$ ) with good ratios of oleic, linoleic, and palmitic acids in 2010 and 2011, respectively, was in response to the application of $150 \mathrm{~kg}$

Table 4. Effect of nitrogen on palmitic and stearic acids, achene yield, and achene oil yield of two sunflower hybrids.

\begin{tabular}{|c|c|c|c|c|c|c|c|c|}
\hline \multirow[b]{2}{*}{ Treatments } & \multicolumn{2}{|c|}{ Palmitic acid in oil } & \multicolumn{2}{|c|}{ Stearic acid in oil } & \multicolumn{2}{|c|}{ Achene yield } & \multicolumn{2}{|c|}{ Achene oil yield } \\
\hline & 2010 & 2011 & 2010 & 2011 & 2010 & 2011 & 2010 & 2011 \\
\hline & & & 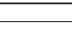 & $\overline{-}$ & 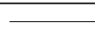 & 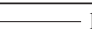 & 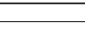 & 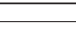 \\
\hline \multicolumn{9}{|l|}{ Hybrids } \\
\hline Hysun-33 & 5.91 & 5.98 & 2.45 & 2.52 & $2980 b$ & $2968 b$ & $1191 b$ & $1209 b$ \\
\hline S-278 & 5.82 & 5.87 & 2.39 & 2.34 & $3350 \mathrm{a}$ & $3380 \mathrm{a}$ & $1405 \mathrm{a}$ & $1423 \mathrm{a}$ \\
\hline LSD value & NS & NS & NS & NS & 17.2 & 11.3 & 39.3 & 35.4 \\
\hline \multicolumn{9}{|l|}{$\mathrm{N}$ levels } \\
\hline $\mathrm{N}_{0}$ (control) & $6.35 \mathrm{a}$ & $6.42 \mathrm{a}$ & $2.27 \mathrm{c}$ & $2.28 \mathrm{c}$ & $2485 c$ & $2456 c$ & $1041 d$ & $1052 \mathrm{~d}$ \\
\hline $\mathrm{N}_{1}\left(75 \mathrm{~kg} \mathrm{ha}^{-1}\right)$ & $5.95 b$ & $6.00 \mathrm{~b}$ & $2.93 \mathrm{a}$ & $2.95 \mathrm{a}$ & $3192 b$ & $3215 b$ & $1333 \mathrm{c}$ & $1348 \mathrm{c}$ \\
\hline $\mathrm{N}_{2}\left(150 \mathrm{~kg} \mathrm{ha}^{-1}\right)$ & $5.90 \mathrm{~b}$ & $5.90 \mathrm{~b}$ & $1.90 \mathrm{~d}$ & $1.91 \mathrm{~d}$ & $3485 \mathrm{ab}$ & $3505 \mathrm{ab}$ & $1418 \mathrm{a}$ & $1433 a$ \\
\hline $\mathrm{N}_{3}\left(225 \mathrm{~kg} \mathrm{ha}^{-1}\right)$ & $5.27 \mathrm{c}$ & $5.38 \mathrm{c}$ & $2.59 b$ & $2.61 b$ & $3498 \mathrm{a}$ & $3521 \mathrm{a}$ & $1395 b$ & $1409 b$ \\
\hline LSD value & 0.375 & 0.374 & 0.302 & 0.301 & 38.89 & 49.70 & 17.7 & 15.9 \\
\hline \multicolumn{9}{|l|}{ Interactions } \\
\hline Hybrids $\times \mathrm{N}$ & NS & NS & NS & NS & NS & NS & NS & NS \\
\hline
\end{tabular}

Any two means not sharing a letter are significantly different at 5\% level of probability (least significant difference LSD); NS: non significant. 
$\mathrm{N} \mathrm{ha}^{-1}$. In contrast, Hysun-33 had a higher protein content $(18.02 \%, 18.23 \%)$ than S-278 in both years.

Efecto de nitrógeno en la proteína, aceite, y perfil de ácidos grasos del aquenio y rendimiento de híbridos de girasol. Parece racional que el rendimiento de semilla y rendimiento de aceite de aquenio sigan siendo el foco determinante para tasas de aplicación de $\mathrm{N}$ en lugar de la composición de la semilla. El N parece jugar un papel imprescindible en la proporción de ácidos grasos insaturados (ácidos oleico y linoleico), factor principal que determina el aceite de girasol (Helianthus annuus L.). Los estudios fueron realizados para evaluar el efecto de la fertilización $\mathrm{N}$ en el rendimiento de semilla, rendimiento de aceite de aquenio, y parámetros de calidad de híbridos de girasol por 2 años sucesivos (2010 y 2011) en un diseño de bloques completos al azar con arreglo de parcelas divididas. Los híbridos (Hysun-33 y S-278) y niveles de N (0, 75, 150 y $225 \mathrm{~kg}$ $\mathrm{ha}^{-1}$ ) fueron asignados a parcelas principales y sub parcelas, respectivamente. Niveles crecientes de $\mathrm{N}$ aumentaron de manera estable el rendimiento, contenidos de proteína y de ácido linoleico en el aceite, donde contenidos de aceite y porcentaje de ácido oleico respondieron negativamente durante ambos años. Al mismo tiempo, el rendimiento de aceite del cultivo permaneció positivamente relacionado al gran suministro de $\mathrm{N}$ dando la ventaja de mayor rendimiento de aquenio (AY). El ácido palmítico varió de 5,27\% a 6,42\% y el ácido esteárico de $2,27 \%$ a $2,95 \%$, respectivamente. 'S278 ' exhibió apreciablemente $(\mathrm{P}<0,05)$ mayores AY $(3380$ $\left.\mathrm{kg} \mathrm{ha}^{-1}\right)$ y contenido de aceite (42.11\%) que 'Hysun-33' (2968 kg ha $\mathrm{kg}^{-1} 40.75 \%$, respectivamente), mientras se observó lo contrario para contenido de proteína. El rendimiento de aceite varió en respuesta a fertilización $\mathrm{N}$, de $34 \%$ a $37 \%$ teniendo mejores rasgos de calidad durante ambas temporadas.

Palabras clave: ácido linoleico, ácido oleico, ácido palmítico, Helianthus annuus.

\section{LITERATURE CITED}

Abbadi, J., and J. Gerendas. 2009. Nitrogen use efficiency of safflower as compared to sunflower. Journal of Plant Nutrition 32(6):929-945.

Abdel-Sabour, M.F., and M.A. Abo El-Seoud. 1996. Effects of organic-waste compost addition on sesame growth, yield and chemical composition. Agriculture, Ecosystems and Environment 60:157-164.

Al-Thabet, S.S. 2006. Effect of plant spacing and nitrogen levels on growth and yield of sunflower (Helianthus annuus L.) Journal of Agricultural Science 19:1-11.

Arshad, M., M. Ilyas, and M.A. Khan. 2009. Genetic divergence and path coefficient analysis for seed yield traits in sunflower (Helianthus annuus L.) hybrids. Pakistan Journal of Botany 39:2009-2015.

Bakht, J., S. Ahmad, M. Tariq, H. Akbar, and M. Shafi. 2006. Performance of various hybrids of sunflower in Peshawar valley. Journal of Agricultural Science 1(3):25-29.

Boydak, E., D. Karaaslan, and H. Turkoglu. 2010. The effect of different nitrogen and irrigation levels on fatty acid composition of peanut oils. Turkish Journal of Field Crops 15:29-33.
Bukhsh, M.A.H.A., J. Iqbal, S. Kaleem, A. Wasaya, and M. Ishaque. 2011. Qualitative analysis of spring planted sunflower hybrids as influenced by varying nutritional area. Pakistan Journal of Nutrition 10:291-295.

Flagella, Z., T. Rotunno, E. Tarantino, R.D. Caterina, and A.D. Caro. 2002. Changes in seed oil yield and oil fatty acid composition of high oleic sunflower hybrids in relation to the sowing date and water regimes. European Journal of Agronomy 17:221-230.

Gao, Q., C. Li, G. Feng, J. Wang, Z. Cui, X. Chen, and F. Zhang. 2012. Understanding yield response to nitrogen to achieve high yield and high nitrogen use efficiency in rainfed corn. Agronomy Journal 104:165-168.

Gholinezhad, E., A. Aynaband, A.H. Ghorthapeh, G. Noormohamadi, and I. Bernousi. 2011. Effect of drought stress and nitrogen rates on grain yield, quality traits and physiological indices in sunflower hybrid Iroflor at different plant density. World Applied Sciences Journal 14:131-139.

Khaliq, A., and Z.A. Cheema. 2005. Influence of irrigation and nitrogen management on some agronomic traits and yield of hybrid sunflower (Helianthus annuus L.) International Journal of Agriculture and Biology 7:915-919.

Munir, M.A., M.A. Malik, and M.F. Saleem. 2007. Impact of integration of crop manuring and nitrogen application on growth, yield and quality of spring planted sunflower (Helianthus annuus L.) Pakistan Journal of Botany 39:441-449.

Nanjundappa, G., B. Shivaraj, S. Janarjuna, and S. Sridhara. 2001. Effect of organic and inorganic sources of nutrients applied alone or in combination on growth and yield of sunflower (Helianthus annuus L.) Helia 24(34):115-120.

Nasim, W., A. Ahmad, A. Bano, R, Olatinwo, M. Usman, T. Khaliq, et al. 2012. Effect of nitrogen on yield and quality of sunflower (Helianthus annuus L.) hybrids under sub humid conditions of Pakistan. American Journal of Plant Science 3:243-251.

Nasim, W., A. Ahmad, A. Wajid, J. Akhtar, and D. Muhammad. 2011. Nitrogen effects on growth and development of sunflower hybrids under agro-climatic conditions of Multan. Pakistan Journal of Botany 43:2083-2092.

Regina, H. 2008. Influence of macro-and micro nutrient fertilization on fungal contamination and fumonisin production in corn grains. Food Control 19:36-43.

Roche, J., M. Alignan, A. Bouniols, M. Cerny, Z. Mouloungi, F. Vear, and O. Merah. 2010. Fatty acid profile composition in sunflower seeds as affected by genotypes and environmental conditions. Food Chemistry 121:990-995.

Ryland,J.2003. Manufacturing and food service. Sunflower Conference Proceedings 2003. Session III. 20 May. Australian Oilseeds Federation, Australia Square, New South Whales, Australia.

Steel, R.G.D., J.H. Torrie, and D.A. Dickey. 1997. Principles and procedures of statistics. A biometrical approach. $3^{\text {rd }}$ ed. p. $400-$ 428. McGraw Hill Book, New York, USA.

Thavaprakash, N., S. Kumar, S.D. Raja, and S. Kumar. 2002. Effect of nitrogen and phosphorus levels and ratios on seed yield and nutrient uptake of sunflower hybrid DSH-I. Helia 25:59-68.

Vega, A.J., and A.J. Hall. 2002. Effects of planting date, genotype, and their interactions on sunflower yield: I. Determinants of oilcorrected grain yield. Crop Science 42:1191-1201.

Wamsely, J. 1998. Simultaneous determination of oil and moisture in seed by NMR. Lipid Technology 10:6.

Zahoor, A., M. Riaz, S. Ahmad, H. Ali, M.B. Khan, K. Javed, et al. 2010. Ontogeny, growth and radiation use efficiency of sunflower (Helianthus annuus L.) as affected by hybrids, nitrogenous regimes and planting geometry under irrigated arid conditions. Pakistan Journal of Botany 42:3197-3207.

Zheljazkov, V.D., B.A. Vick, B.S. Baldwin, N. Buehring, T. Astatkie, and B. Johnson. 2009. Oil content and saturated fatty acids in sunflower as a function of planting date, nitrogen rate, and hybrid. Agronomy Journal 101:1003-1011.

Zheljazkov, V.D., B.A. Vick, M.W. Ebelhar, N. Buehring, B.S. Baldwin, T. Astatkie, and J.F. Miller. 2008. Yield, oil content and composition of sunflower grown at multiple locations in Mississippi. Agronomy Journal 100:635-642. 